\title{
Nurturing the next Canadian generation: The case for labour market research
}

\author{
Kevin McQuillan ${ }^{1}$
}

\begin{abstract}
As rates of population and labour force growth slow in Canada, the country faces important challenges in promoting economic growth and sustaining prosperity. Among the most important public issues are increasing labour force participation rates among groups with low or declining rates of work and reforming education to better prepare graduates for the jobs of the new economy. At the same time, Canada needs to respond to the shifting geography of work. The concentration of employment in a limited number of major urban centres is driving young people to seek work in high-cost cities, while many smaller cities and regions face the prospect of economic and demographic decline.
\end{abstract}

Keywords: slow population growth; young generations; new economy; labour market; education reform.

\section{Résumé}

Alors que les taux de population et la croissance de la population active ralentissent au Canada, le pays devra relever d'importants défis pour promouvoir la croissance économique et maintenir la prospérité. Les plus importantes questions d'ordre public porteront, entre autres, sur le taux de participation, au sein de la population active, de groupes présentant des taux d'emploi faibles ou en déclin et la réforme de l'éducation afin de mieux préparer les diplômés aux emplois de la nouvelle économie. Le Canada doit, en même temps, aborder la géographie changeante du travail. La concentration des emplois dans quelques grands centres urbains pousse les jeunes à chercher du travail dans les villes où le coût est élevé, alors que les villes plus petites et les régions sont confrontées au déclin économique et démographique.

Mots-clés : faible accroissement de la population; jeunes générations; nouvelle économie; marché du travail; réforme de l'éducation.

As the planet moves towards its peak population, Canada's population continues to increase, but at a modest pace and largely due to immigration. In 2016-17, the nation gained just over 100,000 people through natural increase and almost 250,000 through net migration, resulting in a rate of growth of just under 1 per cent. One consequence of the trend to slower growth is a labour force that will age and grow more slowly in the years ahead. This has raised significant concern about the future health of the Canadian economy (Advisory Council on Economic Growth 2017). As a result, preparing the next generation for successful working lives, assisting immigrant workers to find their place in the Canadian labour market, and meeting the shifting needs of employers will be among the most important challenges Canadian society will face in the years ahead.

1. Department of Sociology, University of Calgary, 2500 University Dr. NW, Calgary, AB T2N 1N4; email: kevinmcq@ucalgary.ca. 
Canada has experienced below-replacement fertility for four decades now. Evolutionary biologists argue that low-fertility species typically follow a "K strategy" of heavy investment in a small number of offspring, as opposed to an " $\mathrm{r}$ strategy," characteristic of high-fertility populations, where parents invest limited resources in the face of high rates of mortality (Pianka 1970). Similarly, economic demographers speak of the need for significant investment in the "quality" rather than the quantity of children (Becker and Tomes 1976). As Canada faces what is likely to be a long period of slower population growth and a declining rate of natural increase, promoting the successful development of our children will be critical to protect and improve our standard of living.

\section{Emerging issues}

\section{Labour shortage or labour surplus}

Despite the evident importance of balancing supply and demand in the labour market for both workers and employers, there is a wide gulf between the perceptions of many employers along with some labour market analysts, who perceive a growing shortage of labour, and those of most labour unions and many other analysts, who see a degree of mismatch between the skills of unemployed workers and the needs of employers but no evidence of general shortages now or in the foreseeable future (McQuillan 2013). Moreover, there is growing discussion of the impact of new technological developments that have the potential to eliminate many existing jobs and create a gulf between those employed in high-skill occupations and those with few options outside lowpaying positions in the service sector.

There is no doubt that the growth rate of the labour force is slowing, and the retirement of the baby boom cohorts will lead to higher exit rates from the labour force in the near future. Some observers, including the Advisory Council on Economic Growth, established by Prime Minister Trudeau, have called for aggressive action to counter this decline, including a significant increase in immigration numbers. At the same time, Canada has seen relatively high rates of unemployment in many regions of the country, and new labour market entrants, both Canadian-born and foreignborn, face significant challenges to find work that matches their credentials. Moreover, despite continued low fertility and the imminent departure from the labour market of the baby boomers, some analysts argue that increasing labour force participation rates among older workers, women and immigrants will help to ensure continued growth of the labour force (Belanger and Bastien 2013). Men in the prime working ages constitute a fourth category to include; labour force participation rates for men with lower levels of education have fallen significantly in recent years.

Of course, adequate numbers of new entrants is only part of the issue; meeting the needs of the labour market for the skilled workers in high demand will be the greatest challenge. Rapid shifts in technology and ways of doing business can make some skills irrelevant very quickly, while educational institutions struggle to turn out workers with the new types of skills that are needed to fuel economic growth.

\section{Expansion of higher education and shifting needs of the labour market}

Canada has been remarkably successful in boosting access to education and providing quality education at all levels. Canada ranks second among OECD countries in the proportion of people aged 25-34 with some form of tertiary education (OECD Data 2016). New data from the 2016 Census of Canada (see Table 1) show the rapid growth among recent generations in the proportion with a university education, as well as a growing achievement gap between women and men (Statistics Canada 2017). 
McQuillan: Nurturing the next generation

Table 1. Males and females in Canada with at least a Bachelor's degree, 2016.

\begin{tabular}{cccc}
\hline Age group & Males & Females & Total \\
\hline $25-34$ & 29.1 & 40.7 & 35.0 \\
$35-44$ & 29.3 & 37.4 & 33.4 \\
$45-54$ & 25.4 & 27.1 & 26.3 \\
$55-64$ & 20.9 & 19.6 & 20.3 \\
\hline
\end{tabular}

Source: 2016 Census of Canada (Statistics Canada 2017).

Yet there is growing debate about the adequacy of the preparation students are receiving for entry into the labour market. Among the concerns now being expressed are: graduates lack key skills that are needed in the world of work; there is an excess of graduates in some areas and significant shortages in others; and students lack the skills to drive innovation and new business development (Tal and Mendes 2017).

Some of these fears may be exaggerated-Canada continues to score near the top based on results of the PISA (Program for International Student Assessment) tests. Nevertheless, there has been some erosion of scores, particularly in science and mathematics (OECD 2018). Moreover, Canadians may well ask why a 22.3-per-cent increase in per-student spending over the last decade has produced no improvement in results (MacLeod and Emes 2017).

The imbalance between graduates in particular disciplines and labour market needs is a constant conundrum. There is an important time gap between the emergence of labour shortages and the production of new graduates in these areas. In addition, some critics would argue that the focus needs to be on teaching skills that can be used in many areas rather than focusing solely on producing graduates who can fill particular niches in the labour market. Nevertheless, post-secondary institutions are introducing a flood of new undergraduate and graduate programs, especially in more narrowly defined fields such as data security and business analytics. And rapid shifts in student choice show that young people are keenly attuned to their employment prospects after graduation.

Canada's limited success in promoting entrepreneurialism and business development is a source of much debate. Certainly, Canada has not played a leading role in the technology industries that have transformed advanced economies in recent years. With the decline in resource industries internationally, Canada will need new sources of economic growth to sustain our standard of living. Some blame our sub-standard performance on excessive regulation and high taxes; others point to a culture that has often looked to government or to established champions to be the drivers of innovation; still others complain of the hemorrhaging of talent, especially in the technology sector, to the United States. Whatever the reasons, it is clear that Canada must do better. Postsecondary institutions are increasingly aware of the issue and many are moving to build a greater emphasis on innovation and entrepreneurialism into the curriculum. Cities, too, are putting more emphasis on economic development and experimenting with policies to attract new businesses and to provide support to start-ups that will allow them to grow.

\section{Concentration of economic growth in major cities}

A major challenge for our economy, and for young people in particular, is the increasing concentration of work and opportunity in a small range of cities. This problem has received the most attention in the United States, where the contrast between centres of technological innovation like San Francisco, Boston, Austin and declining industrial centres like Detroit, Cleveland, and Cincinnati is striking (Moretti 2013; Munro 2017). But decline has been evident in many smaller cities and rural areas, too, leaving young people to choose between unemployment or under-employment in their home communities or migration to high-cost cities in search of work. Although the American case has received the most scholarly and media attention, Canada and several European nations are 
experiencing a similar phenomenon. Between 2011 and 2016, 63.8 per cent of Canada's population growth was accounted for by the six largest cities; in the same period, two Census Metropolitan areas and thirty-six Census agglomerations lost population. As in the US, digitization is proceeding rapidly in some cities and industries, while others lag behind. This has been exacerbated by the downturn in many resource industries that has led to employment loss in energy, mining, and forestry. Extending economic growth to more regions and communities and responding to the housing challenges in several of our largest cities must be key policy issues for the years ahead.

\section{Future challenges}

\section{Responding to rapid changes in the demand for labour}

In his prescient 1973 book, The Coming of Post-Industrial Society, Daniel Bell foresaw the shift in advanced societies from an economy based around the production of goods to one anchored in the production of services. With this change came a growing need for a highly educated population that is prepared to tackle problems requiring mental rather than manual skills. Canada has experienced this shift, with significant declines in the proportion of workers in farming, manufacturing, and resource industries and huge growth in service industries. At the occupational level, the transformation has been even more intense, with rapid growth in demand for workers in jobs that did not exist even ten years ago. Anticipating shifts in the demand for labour and designing policies that help Canadian workers to respond will be a key challenge for the country.

\section{Reforming education to prepare for a changing economy}

The extraordinary expansion of higher education in Canada since the 1960s has allowed us to compete reasonably well in the new economy and has sustained our high standard of living. But rapid changes in Canada's economy, the potential for slower economic growth, and the departure of the baby boom generation will pose new challenges for our education system. Meeting the needs for workers with the right skills in an era of slower labour force growth will require changes at all levels of the school system. Three areas demand special attention:

1. Expanding and improving early childhood education. Canada currently has a patchwork system for providing education to youngsters prior to entry into elementary schools. Although there is an ongoing debate on the contribution of preschool programs to later academic success, it seems clear that in a properly designed system, earlier schooling can help build skills, especially among children from disadvantaged backgrounds, which will improve their achievement at school. Moreover, better provision of early childhood education will allow for increases in labour force participation rates, especially among young mothers, that can help offset slower labour force growth. Designing and funding the best systems for early childhood learning is a key challenge for the future.

2. Reforming the post-secondary system. When less than 10 per cent of each generation attended university, a degree was a virtual guarantee of employment. With more than one in three young people now graduating from university, and more than 60 per cent obtaining some form of post-secondary credential, that is no longer the case (Norris 2011). Canada has built a post-secondary system that has succeeded in broadening access while maintaining high standards of learning. The challenge for the future will be maintaining broad participation while developing new programs and principles of instruction that better prepare graduates for success in the labour market. 
3. Improving access to lifelong learning. Slower labour force growth demands better utilization of the existing workforce. This is best accomplished by increasing participation rates among under-represented groups such as recent immigrants and older workers. But doing this will require improving training programs to allow immigrants taught under different systems to succeed in the Canadian labour market and to help older workers update their skills that will help them extend their careers.

\section{Expanding our knowledge base}

It is surprising that our knowledge of the labour market is so limited. The debate over the existence of a labour shortage is eloquent testimony to the limits of current knowledge. Why do businesses perceive such difficulty in finding the right workers while job-seekers complain of limited opportunity? Why are rates of internal migration falling when the need to move to find a good job has never been greater? Good research can answer these questions. Bringing together government and academic analysts with human resource specialists would be a good first step to improving our understanding of this critical issue for Canada's future.

\section{References}

Advisory Council on Economic Growth. 2017. The Path to Prosperity: Resetting Canada's Growth Trajectory. https://www.budget.gc.ca/aceg-ccce/pdf/pathway-to-prosperity-eng.pdf

Becker, G.S., and N. Tomes. 1976. Child endowments, and the quantity of children. Journal of Political Economy 84(4):S143-S162.

Bélanger, A., and N. Bastien. 2013. The future composition of the Canadian labor force: A microsimulation projection. Population and Development Review 39:509-25.

Bell, D. 1973. The Coming of Post-Industrial Society: A Venture in Social Forecasting. New York: Basic Books.

MacLeod, A., and J. Emes. 2017. Education Spending and Student Enrolment in Canada: 2017 Edition. Fraser Institute Research Bulletin. Vancouver: Fraser Institute.

McQuillan, K. 2013. All the workers we need: Debunking Canada's labour-shortage fallacy. The School of Public Policy: SPP Research Papers 6(16):1-28.

Moretti, E. 2013. The New Geography of Jobs. Boston and New York: Mariner Books.

Munro, M. 2017. Tech empowers, tech polarizes. Brookings: The Avenue, 21 November 2017. https://www.brookings.edu/blog/the-avenue/2017/11/21/tech-empowers-tech-polarizes

Norris, D. 2011. A half-century of change in Canada's labour force. Environics Analytics, 26 June 2011. http://www.environicsanalytics.ca/environics-analytics/blog/doug-norris/doug-norrisblog/2013/06/26/a-half-century-of-change-in-canada-s-labour-force

Pianka, E.R. 1970. On r- and K- selection. The American Naturalist 104:592-97.

Statistics Canada. 2017. Highest Level of Educational Attainment by Sex and Selected Age Groups. Catalogue No. 98-402-X2016010. Release date: 29 November 2017.

Tal, B., and R. Mendes. 2017. Education and employability: Can we close the gap? CIBC Capital Markets: In Focus, 29 August 2017.

OECD. 2018. PISA 2015: Results in Focus. http://www.oecd.org/pisa/pisa-2015-results-in-focus.pdf

OECD Data. 2016. Population with Tertiary Education. https://data.oecd.org/eduatt/populationwith-tertiary-education.htm 